Ingvill Krogstad Svanes OsloMet

Anne Kristine Øgreid

OsloMet

DOI: http://dx.doi.org/10.5617/adno.7758

\title{
«Jeg vet ikke hva jeg skal skrive om!» - Læreres stillasbygging i oppstarten av skrivesituasjoner på barnetrinnet
}

\begin{abstract}
Sammendrag
Muntlig veiledning i skriving kan være krevende for lærere siden skrivesituasjoner er komplekse, og læreren har liten mulighet til å reflektere rundt og omformulere det som blir sagt. Denne studien undersøker to læreres veiledning i oppstarten av skrivesituasjoner på barnetrinnet. Elevene på 3. trinn skriver fortellinger og har fått relativt frie oppgaver. Det viser seg at det er utfordrende for noen elever å bruke fantasien for å generere idéer, de vet ikke hva de skal skrive om. Studien undersøker de to lærernes veiledning i disse situasjonene. Den bygger på teori om stillasbygging og diskuterer på hvilken måte lærernes veiledning kan forstås som en del av en stillasbyggingsprosess. Artikkelen bygger på videoobservasjon av de to lærernes undervisning, og utdrag fra oppstartssituasjoner blir analysert med utgangspunkt i fem ulike stillasbyggingsstrategier: tilbakemelding, hint, instruksjoner/forklaringer, modellering og spørsmål. Resultatene viser at lærerne bruker ulike stillasbyggingsteknikker og i ulik grad. De stiller mange spørsmål for at elevene skal få idéer, og spørsmålene har svært ulike funksjoner. Den ene læreren stiller spørsmål for å redusere elevenes valgmuligheter, mens den andre læreren modellerer mange idéer for å vise elevene at det finnes flere muligheter. Artikkelen bidrar med kunnskap om hvordan lærere veileder elever i skriving før det finnes tekst å veilede på. En studie som denne kan gi økt bevissthet rundt det komplekse i skriveveiledning. Læreren må ha klart for seg enkeltelevenes behov eller utfordringer. Hun trenger også fagdidaktisk kunnskap som må sitte i ryggmargen, fordi det er liten tid til å tenke seg om.
\end{abstract}

Nøkkelord: skriveopplæring, skriveveiledning, stillasbygging, stillasbyggingsstrategier, barnetrinnet

\section{«I don’t know what to write about!» - Teachers' scaffolding in the start-up of writing situations}

\begin{abstract}
Oral guidance in writing may be demanding for teachers since writing situations are complex, and the teacher has little opportunity to reflect on and rephrase what is being said. This study examines two teachers' scaffolding in the start-up of writing situations at the primary level. The pupils in 3rd grade are writing stories based on relatively free tasks. It turns out that it is challenging for some pupils to use their imagination to
\end{abstract}


generate ideas, they do not know what to write about. The study examines two teachers' scaffolding in these situations. The backdrop is scaffolding theory, and the discussion revolves around how teachers' help can be understood as part of a scaffolding process. The article builds on video observations of the two teachers' teaching, and excerpts from start-up situations are analyzed based on five different scaffolding strategies: feedback, hints, instructions/explanations, modeling and questioning. The results indicate the use of different scaffolding strategies to varying degrees. The teachers ask many questions which have different functions. One of the teachers asks questions to reduce the pupils' options, while the other teacher models many ideas to show pupils that there are many opportunities. The article contributes with knowledge about teachers' writing instruction before a text is written. This study might give increased awareness about the complexity of scaffolding in writing. The teacher has to know the individual pupil's needs and challenges. She also needs pedagogical content knowledge, as there is little time to think and reflect in these situations.

Keywords: writing, writing instruction, scaffolding, scaffolding strategies, primary school

\section{Innledning}

Skriving er en krevende aktivitet som innebærer at skriveren må ta en rekke valg underveis i arbeidet med en tekst (Kellogg, 2008; Van de Pol, Volman, \& Beishuizen, 2010). Et av de første valgene gjelder innholdet; det teksten skal handle om. Å generere skriveidéer er utfordrende for en del elever (Dockrell, Lindsay, Connelly \& Mackie, 2007; Dunn \& Finley, 2010), særlig innenfor en kreativitetsdiskurs der tekstkvalitet er knyttet til personlig stil, interessant innhold og litterær verdi (Ivanič, 2004). I grunnskolen kommer kreativtetsdiskursen gjerne til uttrykk gjennom fortellingssjangeren med relativt frie oppgaver og der den enkelte elevs fantasi er en helt sentral ressurs. Mange elever søker støtte hos læreren gjennom det velkjente sukket: «Jeg vet ikke hva jeg skal skrive om!» I denne artikkelen studerer vi hvordan to lærere støtter enkeltelever som strever med å få idéer til hva en fortelling skal handle om. Formålet med studien er å sette fokus på skrivelærerens individuelle stillasbygging i idéfasen, som et supplement til den mangfoldige forskningen på lærerens respons på elevers tekstutkast underveis og mot slutten av skriveprosessen (Bueie, 2015, 2016; Igland, 2009; Kvithyld \& Aasen, 2011; Larsen, 2011; Lorentzen, 2014).

Stillasbygging (scaffolding) er blitt et anvendelig begrep i skoleforskning for å beskrive hvordan læreren, som en mer kompetent annen, støtter elever i å løse konkrete utfordringer innenfor deres nærmeste utviklingssone (jf. Vygotsky, 1978) der målet er at støtten på sikt skal internaliseres som del av elevenes repertoar for problemløsning (Wood, Bruner, \& Ross, 1976). Stillasbygging dreier seg altså ikke bare om å støtte enkelteleven i å fullføre en konkret oppgave, det dreier seg også om at eleven settes i stand til å løse tilsvarende oppgaver på egen hånd i fremtiden (Maybin mfl., 1992 i Mercer, 1994). På tross av at uttrykket 
«nærmeste utviklingssone» hos Vygotsky gjelder enkeltindividet, er det i en rekke klasseromsstudier, også i forbindelse med skriving, knyttet til støtte rettet mot elevkollektivet (Håland, 2013; Kverndokken, 2014; Matre, 2009; Øgreid, 2016). I en skrivedidaktisk sammenheng dreier det seg blant annet om å skape meningsfulle skrivesituasjoner for elevene (se f.eks. Bakke \& Skovholt, 2015; Hopperstad \& Semundseth, 2013; Semundseth, 2010) slik at de opparbeider seg skriveoverskudd for den individuelle tekstskapingen. På tross av dette vil en del elever likevel streve med å komme i gang og vil trenge en mer individuell lærerstøtte gjennom «face-to-face interactions» (Van de Pol mfl., 2010, p. 272). Til forskjell fra fellesaktiviteter i oppstartsfasen har læreren gjennom individuelle samtaler mulighet til å bygge stillas ut fra enkeltelevens eksisterende utviklingsnivå når eleven selv initierer behov for støtte.

Van de Pol mfl. (2010) hevder i en oversiktsartikkel knyttet til begrepet «scaffolding» i skolen at forutsetningen for at en aktivitet kan betraktes som stillasbygging, er bestemt av tre hovedkriterier; contingency, fading og transfer of responsibility. De to siste henger sammen og omhandler elevenes internalisering og selvstendige bruk av støtten. Fading refererer til lærerens gradvise tilbaketrekking av støtte, mens transfer of responsibility dreier seg om at eleven i økende grad overtar ansvaret for egen læringen. I denne studien er det imidlertid det første kriteriet, contingency, som er interessant fordi det knyttes til samspillet mellom lærer og elev i en en-til-en-situasjon der tilpasningen til den enkelte elev er det sentrale. Contingency oversettes også med uttrykket betinget stillasbygging (Davidsen \& Aamaas, 2017), der stillasbygging forstås som betinget av den konkrete situasjonen med utgangspunkt i elevens behov. Stillasbygging forstått i dette perspektivet kan altså ikke planlegges slik en lærer vanligvis planlegger undervisningssekvenser, men støtten er betinget av det som skjer i samtalen mellom lærer og elev omkring enkeltelevens konkrete utfordringer. For å få mer kunnskap om stillasbygging i dette perspektivet vil vi undersøke følgende problemstilling gjennom videodata av to lærere på 3. trinn som veileder elever i oppstarten av skrivesituasjoner: Hva kjennetegner lcerernes veiledning når elevene skriver fortelling, og på hvilken måte kan veiledningen forstås som del av en stillasbyggingsprosess?

\section{Skrivelæreren som stillasbygger}

Forskning på stillasbygging i klasserom er mangfoldig, og det er gjort ulike forsøk på å systematisere hvilke teknikker eller strategier den som bygger stillaser bruker (se f.eks. Tharp \& Gallimore, 1989; Wood mfl., 1976). I denne artikkelen vil vi med utgangspunkt i Van de Pols (2010) generelle tilnærming til stillasbygging redegjøre for forskning som særlig befatter seg med stillasbygging rettet mot elevers tekstskaping. Van de Pol mfl. (2010) finner at stillasbygging kan ordnes i følgende seks kategorier etter de strategiene (means of scaffolding) lærerne bruker 
for å bygge stillas: å gi tilbakemeldinger (feeding back), hint (hints), instruksjoner (instructing), forklaringer (explaining), modellering (modeling) og spørsmålsstilling (questioning). Forskningsgjennomgangen nedenfor er avgrenset til skriving på barnetrinnet og forskning der lærerens rolle er vesentlig.

Tilbakemelding som stillasbygging innebærer at elevene får lærerens reaksjon på et skolearbeid de har utført. For at noe skal kunne betegnes som tilbakemelding, må det være noe å melde tilbake på, og i skriveundervisningen vil det hovedsakelig være elevens tekst. For at tilbakemelding på elevtekster skal fungere som stillas, må den for det første samsvare med elevenes nivå og læreren må følgelig ha kunnskap om hvordan elevene kan utvikle seg som skrivere (Glasswell \& Parr, 2009). Læreren må også tenke framover, ikke bare fokusere på det som allerede er gjort (Hawe, Dixon, \& Watson, 2008). Formen på tilbakemeldingene er et annet vesentlig aspekt. Eleven bør utfordres framfor å få servert et ferdig svar på et spørsmål (Dunn \& Finley, 2010; Thurlings, Vermeulen, Bastiaens, \& Stijnen, 2013), og i flere studier pekes det på verdien av at elevene får bekreftelser på positive faglige aspekt ved tekstene, framfor ikke-spesifikk ros som «kjempebra!» (Engelsen, Eide, \& Meling, 2009). Ros av typen «kjempebra!» kan imidlertid være utgangspunktet for mer utfyllende tilbakemeldinger (Wong \& Waring, 2009) og er viktig for elevenes selvbilde og relasjonen mellom lærer og elev. Dette kan igjen virke positivt på motivasjonen (Voerman, Korthagen, Meijer \& Simons, 2014).

Når læreren bruker hint, hentyder hun noe for elevene, ofte veien mot et riktig svar, eller kommer med forslag for å få eleven videre i prosessen (Van de Pol mfl., 2010). I engelskspråklig sammenheng forstås begrepet hint noe videre enn på norsk, som råd og tips, ikke bare som sterke hentydninger. Van de Pol mfl. (2010) understreker at hvis hint skal fungere som stillasbygging, krever det at læreren gir hentydning eller råd og så trekker seg tilbake, slik at eleven må løse resten av problemet selv. Det er, ikke uventet, vanskelig å finne forskning på hint som stillasbygging spesielt knyttet til skriveundervisning. På et noe mer generelt grunnlag diskuterer Myhill og Warren (2005) om samtaler i klasserommet virkelig fungerer som midlertidige stillas, eller om de også kan fungere som press (heavy prompts) og «tvangstrøyer» for elevene. Et kritisk moment her er om læreren bygger videre på elevens tidligere kunnskaper og erfaringer og på det eleven sier (Myhill \& Warren, 2005).

De to neste kategoriene, instruksjoner og forklaringer, har vi valgt å se i sammenheng fordi vi oppfatter dette som gradsforskjeller av samme fenomen. I Van de Pols (2010) studie innebærer instructing at læreren forteller eleven hva han skal gjøre eller forklarer hva han må gjøre, hvordan eller hvorfor. Explaining innebærer at læreren gir mer detaljert og oppklarende informasjon. En type inngripen når elevene skriver, skjer for å gi eksplisitte instruksjoner, informasjon og forklaringer, ofte i et forsøk på å få eleven til å endre noe eller forbedre teksten (Englert, Mariage, \& Dunsmore, 2006). Denne typen samtaler kan være med på å avklare lærerens forventninger til elevens skriving (Hawe mfl., 2008) og kan ses 
i sammenheng med det «å gi svaret» som tilbakemeldingsstrategi (se ovenfor). I skrivedidaktikken er det satt fokus på eksplisitt skriveundervisning, for eksempel når det gjelder sjangerundervisning og gjennom bruk av skriverammer og modelltekster (Håland, 2013; Øgreid, 2018). I denne studien er det derimot aktuelt å se eksplisitt undervisning $\mathrm{i}$ en individualisert kontekst der læreren gir «privatundervisning» ved pulten der hun instruerer eller forklarer (se også O'Keefe, Xu \& Clarke, 2006).

Modellering handler ifølge Van de Pol og kolleger (2010) om at læreren demonstrerer eller viser noe som elevene kan imitere. Modellering kan skje på makronivå ved at læreren bruker modelltekster som utgangspunkt for skriving (se f.eks. Håland, 2013). Gjennom en studie av samtaler rundt modelltekster skisserer Håland (2018) tre didaktiske element som hun hevder er kvalitetstrekk ved samtaler om modelltekster; læreren bør gjennom samtalene stimulere elevene til å oppdage tekstlige mønstre i en modelltekst, utforske trekkene i egen tekst, og til slutt utfordre mønstrene ved å vurdere alternative løsninger. Modellering kan også skje på mikronivå, gjennom individuelle samtaler mellom lærer og elev (Håland, 2018). Da kan læreren modellere strategier for å støtte opp om elevenes kognitive og metakognitive aktiviteter, noe som blant annet kan skje ved at læreren tenker høyt (Regan \& Berkeley, 2012). Modellering gjennom samtaler er en konkret måte å bygge stillaser på, det er derimot ikke så ofte brukt (Parker \& Hurry, 2007; Svanes \& Klette, 2017).

Bruk av spørsmål som stillasbygging vil si å stille spørsmål til elevene som krever et aktivt språklig eller kognitivt svar (Van de Pol mfl., 2010). Forskning på bruk av spørsmål er en del av samtaleforskningen, og bygger som regel på helklassesamtaler. Sentralt i særlig en tidlig periode av denne forskningen er funnet av IRE/F-mønsteret, altså at lærere tar et initiativ (I), eleven responderer på dette (R), hvorpå læreren gir en evaluering (E) eller feedback (F) (f.eks. Cazden \& Beck, 2003). Initiativet i samtalen skjer ofte ved hjelp av spørsmål, og lærere stiller mange spørsmål (Cazden, 2001; Mercer \& Littleton, 2007). Et interessant funn i denne sammenhengen er Davidsons observasjoner fra skrivesituasjoner med de yngste elevene. Hun finner at i en-til-en-situasjoner er det ofte eleven som står for initiativet, ikke læreren. Lærere svarer imidlertid ofte på elevenes spørsmål ved å stille et nytt spørsmål (Davidson, 2007, 2008).

I forskning på læreres bruk av spørsmål skilles det ofte mellom åpne og lukkede spørsmål, der de åpne spørsmålene foretrekkes med tanke på læring (f.eks. Cazden \& Beck, 2003; Myhill, 2006). Nyere forskning har imidlertid vist at dette skillet kan være noe forenklet. Åpne spørsmål trenger ikke nødvendigvis føre til refleksjon og dypere læring, og lukkede spørsmål kan også få elevene til å reflektere og tenke selv (Andersson-Bakken, 2014). Ifølge Myhill (2006) er det spørsmålenes funksjon som er det mest sentrale for læring, og hun skiller blant annet mellom spørsmål som gjenkaller fakta og informasjon, repetisjonsspørsmål, spørsmål som sjekker forkunnskaper, spørsmål som fremkaller svar gjennom 
ledetråder eller hint, og spørsmål som sjekker elevenes forståelse (se også Svanes \& Andersson-Bakken, 2018).

I denne delen om tidligere forskning har vi gitt oversikt over sentrale stillasbyggingsstrategier lærere bruker og knyttet dem til skriveundervisning på barnetrinnet. Van de Pol og kollegers kategorier kan være både overlappende og på ulike nivåer, for eksempel kan bruk av spørsmål være en del av læreres tilbakemelding, eller fungere som hint. Dette kommer vi tilbake til i diskusjonsdelen av artikkelen. Vi finner likevel disse kategoriene meningsfulle med hensyn til denne studiens problemstillinger, og vi tar dem med oss videre som analytisk rammeverk i undersøkelsen av lærerens stillasbygging når elever strever med oppstarten av skrivingen.

\section{Materiale og metode}

\section{Utvalg og datamateriale}

Denne studien er en kasusstudie der vi undersøker hva to lærere gjør i oppstarten av skrivesituasjoner. Materialet er hentet fra en større kvalitativ studie som undersøkte seks læreres individuelle veiledning i norsktimer på 3. trinn (Svanes, 2016). Lærerne ble observert i alle norsktimer en uke hver og intervjuet i etterkant av observasjonene. De to lærerne er valgt ut for denne artikkelen fordi de viste seg å være de eneste som arbeidet med skriving av lengre tekster de ukene observasjonene foregikk, og utvalget er derfor det vi kaller et strategisk utvalg (Flyvbjerg, 2010). Vi har kalt de to lærerne Ellen og Anne. Begge er erfarne lærere, utdannet allmennlærere, og begge har videreutdanning i norsk. Ellen hadde 21 elever i klassen, og Anne hadde 18.

Primærmaterialet for denne artikkelen er videoobservasjonen av lærerne. De ble filmet med to videokameraer; ett oversiktskamera som filmet hele klassen, og ett videokamera som fulgte læreren. Begge kameraene var faste og ble styrt ved hjelp av forskerens PC. Læreren hadde også en trådløs mikrofon som fanget samtalene mellom læreren og elevene når læreren gikk rundt og veiledet. Siden lærerne er filmet en hel uke, inkluderer videoobservasjonene både arbeidet i førskrivingsfasen og tiden når elevene skrev individuelt. Forarbeidet for hver av klassene er nærmere beskrevet i analysedelen av artikkelen. At begge lærerne brukte 21 minutter på dette arbeidet, er tilfeldig. Vi bruker forarbeidet til skrivingen som bakgrunnsinformasjon, mens lærerens arbeid når elevene skrev, er valgt ut som datamateriale og kilde til næranalyser.

Den individuelle skrivingen utgjorde 32 minutter i Ellens undervisning og 47 minutter i Annes, fordelt på to økter hos hver av dem. I denne tiden oppsto det 64 veiledningssituasjoner, 33 i Ellens timer og 31 i Annes. En veiledningssituasjon er definert som tidspunktet fra når læreren kommer til elevens pult til hun går derfra igjen (step in - step back, Englert, Mariage \& Dunsmore, 2006). Kriteriet for at det skal kalles en veiledningssituasjon, er at det må inkludere samtale. 
Innholdet i de 64 veiledningssituasjonene spenner fra elevens behov for hjelp til idéer, til rettskriving eller til å konsentrere seg. 26 av disse veiledningssituasjonene, altså 40\%, handlet om at eleven trengte hjelp til å få idéer i skrivingen, et behov elevene hadde i alle faser av skriveprosessen. Av disse 26 veiledningssituasjonene er 14 knyttet til oppstarten av skrivingen, og det er de som utgjør vårt materiale. Tabell 1 viser oversikt over veiledningssituasjonene.

Tabell 1: Oversikt over veiledningssituasjonene. Pilene indikerer prosessen for reduksjon av utvalget fra alle veiledningssituasjoner til de utvalgte analyserte veiledningssituasjonene.

\begin{tabular}{|l|l|l|l|l|}
\hline $\begin{array}{l}\text { Tid } \\
\text { observert }\end{array}$ & $\begin{array}{l}\text { Veiledningssituasjoner } \\
\text { totalt }\end{array}$ & $\begin{array}{l}\text { Veiledningssituasjoner } \\
\text { der eleven trenger } \\
\text { idéer i skrivingen }\end{array}$ & $\begin{array}{l}\text { Veiledningssituasjoner } \\
\text { om idéer i oppstart av } \\
\text { skriving }\end{array}$ \\
\hline Ellen & $32 \mathrm{~min}$ & 33 & 18 & 8 \\
\hline Anne & $47 \mathrm{~min}$ & 31 & 8 & 6 \\
\hline Sum & $1 t 19 \mathrm{~min}$ & 64 & 26 & 14 \\
\hline
\end{tabular}

Som sekundærmateriale for artikkelen bruker vi intervjuer av de to lærerne. Intervjuene var semistrukturerte, med utgangspunkt $i$ en intervjuguide. Intervjuene var også videostimulerte, noe som betyr at forskeren som intervjuet hadde valgt ut situasjoner fra videoobservasjonene som læreren ble bedt om å kommentere. I artikkelen brukes elementer fra intervjuene der de kan belyse og gi dypere forståelse for lærernes veiledning i skrivesituasjonene.

Dette datamaterialet har noen begrensninger. Utvalget består av to lærere, og skriveøktene har begrenset omfang. Det vil også være vanskelig å si noe om hvorvidt lærernes stillasbygging faktisk leder til varig læring, siden vi undersøker bare første del av en stillasbyggingsprosess. Denne typen nærstudier kan imidlertid fungere som eksempler på situasjoner som kan forekomme i klasserom, og gi oss dypere innsikt i områder som er lite utforsket. I dette ligger «eksempelets makt» (Flyvbjerg, 2010).

\section{Analytisk rammeverk}

Som analytisk rammeverk tar vi utgangspunkt i Van de Pols (2010) kategorier av stillasbyggingsstrategier som vi mener gjenspeiler de viktigste måtene lærere bygger stillaser på. Tabellen nedenfor viser hvordan vi har forstått de ulike kategoriene spesifikt knyttet til oppstarten av skrivesituasjoner, med eksemplifiseringer fra datamaterialet i denne studien. I tråd med den tidligere forskningsgjennomgangen utgjør «instruksjoner og forklaringer» en og samme kategori. 
Tabell 2: Kategorier for analyse av læreres strategier i stillasbygging (Van de Pol mfl., 2010) med eksempler fra eget datamateriale

\begin{tabular}{|c|c|c|}
\hline Kategori & Beskrivelse & Eksempel \\
\hline 1. Tilbakemelding (TM) & $\begin{array}{l}\text { Læreren reagerer på } \\
\text { elevens aktivitet gjennom } \\
\text { for eksempel å svare på } \\
\text { spørsmål, bekrefte eller } \\
\text { avkrefte utsagn fra eleven } \\
\text { eller kommentere noe } \\
\text { konkret eleven har skrevet. }\end{array}$ & $\begin{array}{l}\text { Ja, men...men, her har du } \\
\text { skrev... her har du skrevet } \\
\text { en veldig fin innledning, } \\
\text { [navn på eleven]. Hør, skal } \\
\text { jeg lese den for deg, så skal } \\
\text { du høre hvor flott den er. } \\
\text { (fra utdrag 4) }\end{array}$ \\
\hline 2. Hint $(\mathrm{H})$ & $\begin{array}{l}\text { Læreren hinter } \text { eller } \\
\text { foreslår mer direkte } \\
\text { hvordan eleven skal gå } \\
\text { videre i prosessen. }\end{array}$ & $\begin{array}{l}\text { Passer det sammen? Den } \\
\text { flotte innledningen, passer } \\
\text { det til å fortsette med der? } \\
\text { (fra utdrag 4) }\end{array}$ \\
\hline $\begin{array}{l}\text { 3. Instruksjoner og forklaringer } \\
\text { (I\&F) }\end{array}$ & $\begin{array}{l}\text { Læreren forteller eller } \\
\text { forklarer elevene hva de } \\
\text { skal eller bør gjøre, og } \\
\text { eventuelt utdyper gjennom } \\
\text { mer informasjon. }\end{array}$ & $\begin{array}{l}\text { Så hopper du over linje så } \\
\text { det blir nytt avsnitt. } \\
\text { (fra utdrag } 3 \text { ) }\end{array}$ \\
\hline 4. Modellering (M) & $\begin{array}{l}\text { Læreren demonstrerer eller } \\
\text { viser noe, som elevene kan } \\
\text { imitere. }\end{array}$ & $\begin{array}{l}\text { Sånn...kanskje en dag var } \\
\text { bjørnen ute og gikk tur i } \\
\text { skogen også møtte den en } \\
\text { musefamilie som begynte å } \\
\text { gnage på halen hans. } \\
\text { (fra utdrag 4) }\end{array}$ \\
\hline 5. Spørsmålsstilling (SS) & $\begin{array}{l}\begin{array}{l}\text { Læreren stiller spørsmål, } \\
\text { eller bruker }\end{array} \\
\text { setningsekvivalenter, som } \\
\text { også har funksjon som et } \\
\text { spørsmål. }\end{array}$ & $\begin{array}{l}\text { Har du bestemt deg for } \\
\text { hvem som skal vare } \\
\text { hovedpersonen? } \\
\text { (fra utdrag } 1 \text { ) }\end{array}$ \\
\hline
\end{tabular}

$\AA$ omarbeide induktivt utarbeidede kategorier fra en oversiktsartikkel til deduktive analytiske kategorier har i det minste to utfordringer. For det første er ikke kategoriene gjensidig utelukkende, noe som kan gjøre skillet mellom og statusen til kategoriene uklar. En utfordring som raskt dukket opp, var at spørsmålsstilling ikke er på samme nivå som de andre kategoriene. Spørsmål, som i bunn og grunn er en setningstype, har ulike funksjoner som kan være overlappende med de andre kategoriene. Som eksemplet i kategori 2 ovenfor viser, kan spørsmålene for eksempel være ment som hint til eleven. Vi har løst dette ved å fokusere på spørsmålenes funksjon i analysen, ikke form. Konkret innebærer det for eksempel at der spørsmålet etter vår vurdering fungerer som et forslag, eller at læreren demonstrer noe som kan imiteres av eleven, har vi kategorisert spørsmålene som henholdsvis hint og modellering. De spørsmålene som vi har plassert i kategorien spørsmålsstilling, kan karakteriseres som mer åpne, i den forstand at vi ikke kan se at læreren leder eleven i en spesifikk retning med spørsmålene, men prøver å finne ut hva eleven faktisk tenker. 
En annen utfordring er at situasjoner kan falle på utsiden når kategoriene er forhåndsdefinerte. A kategorisere gjør det imidlertid mulig å systematisere videodata og å uttale seg om materialet som en helhet (Mercer, 2010), slik at vi kan si noe overordnet om lærernes stillasbygging i oppstartsituasjoner. De konkrete utfordringene med kategoriseringen vil vi komme tilbake til avslutningsvis i artikkelen.

\section{Analyse av oppstartsituasjoner}

I det følgende analyserer vi fire transkriberte videoutdrag fra undervisningen, to fra Ellens undervisning og to fra Annes, som vi mener er typiske eksempler på hvordan de to lærerne veiledet elevene. Vi finner altså flere liknende situasjoner i materialet både når det gjelder hvilke stillasbyggingsstrategier lærerne bruker, og lengden på veiledningssituasjonene. Vi bruker følgende forkortelser i tekstutdragene:

TM: Tilbakemelding

H: Hint

I\&F: Instruksjoner og forklaringer

M: Modellering

SS: Spørsmålsstilling

\section{Situasjoner fra Ellens undervisning}

Som forarbeid til elevenes egen skriving leste Ellen innledningen av en fortelling. Elevene diskuterte så hva de fikk vite i innledningen, hva som bør være med i en innledning, og de fikk fantasere om hva som kunne skje videre i denne fortellingen. Elevene fikk så velge et bilde som utgangpunkt for egen skriving. De kunne velge mellom blant annet kunstkort og utklipp av bilder fra blader og aviser. Bildene kunne være barnlige, for eksempel et bilde av Ole Brumm, eller mer aldersnøytrale, for eksempel et bilde av Munchs Skrik eller en fotballkamp. Etter en inspirasjonsøkt skulle elevene skrive en fortelling med utgangspunkt i det bildet de hadde valgt. Situasjonen vi ser i det første utdraget, oppstår noen minutter etter at Ellen har sagt at elevene kan starte skrivingen. Eleven sitter og ser ut i lufta. Han skriver ikke og har ikke rukket opp hånda. Læreren går bort til ham.

\section{Utdrag 1}

00:06:24 - 00:06:56

1. Lærer: Har du bestemt deg for hvem som skal være hovedpersonen? (SS)

2. Eleven trekker på skuldrene.

3. L: Nei. (TM) Hva heter han? (SS) Bruk fantasien din. (I\&F)

4. Elev: Ole 
5. L: Ole, okay. (TM)

6. Hva er det som skal skje med Ole? (SS)

7. Eleven trekker på skuldrene.

8. L: Hvor er han hen nå? (SS)

9. E: På skolen.

10. L: Ja. (TM)

11. Kan du begynne med det? (I\&F)

Eleven nikker. Læreren går videre. Eleven begynner umiddelbart å skrive. I løpet av økta er læreren innom eleven en gang til og ser at han har kommet i gang.

Det første som slår oss ved lærerens veiledning, er hvor mange spørsmål hun stiller ( $\mathrm{N}=5)$. Det siste spørsmålet (linje 11) har funksjon som en instruksjon, det betyr trolig «Nå kan du starte med dette.», og det er derfor markert som I\&F. Ellen gir også en instruksjon til eleven om å bruke fantasien (linje 3). Dette kan tolkes som et signal på at læreren vil ha eleven over i kreativitetsdiskursen og gjøre det tydelig for ham at dette ikke trenger å være «sant». Den neste situasjonen vi skal se nærmere på, oppstår et par minutter etter den første. Denne eleven har rukket opp hånden, og læreren kommer bort til henne.

\section{Utdrag 2}

00:08:44 - 00:09:37

1. Lærer: Hva ser du på bildet? (SS)

2. Elev: [Hvisker] En jente

3. L: $M m$.. (TM)

4. Hva mer enn en jente? [Pause.] (SS) Ser du noe mer? (SS)

5. E: $M m$. [Peker på noe på bildet.]

6. L: En saks. Mm. (TM) Hva tror du den jenta skal med den saksa? (SS)

7. E: Klippe ut en sol.

8. L: Klippe ut en sol, kanskje. Mm. (TM) Hvorfor det? Hva skal hun bruke

9. den sola til, tror du? (SS)

10. E: Lime på ark.

11. L: Kanskje hun skal lime det på et ark. Mm. (TM) Hvor er hun hen da? (SS)

12. E: På skolen.

13. L: På skolen. Mm. Bra. (TM)

14. L: Da kan du begynne å skrive ned noe av det vi har snakket om. Mm. Og så 15. skal vi se om vi klarer å lage en liten historie av det. (I\&F)

Eleven tar fram pennalet og tar ut blyant og viskelær. Etter 2 min og 10 sek begynner hun å skrive. Hun får veiledning to ganger til i løpet av økta.

Også i dette utdraget ser vi at læreren stiller mange spørsmål (N=7). Vi ser at læreren varierer mellom åpne og mer konkrete spørsmål. Spørsmålene i linje 1, 4 og 11 er relativt konkrete og stilles til bildet eleven har valgt. Samtidig ønsker læreren at eleven skal bruke fantasien og tenke selv (linje 6, 8 og 9), og stiller 
derfor mer åpne spørsmål. I videoopptaket fremstår eleven som svært usikker, og hun snakker lavt. Når læreren aktivt bekrefter det eleven sier (markert som TM), kan dette forsterke for eleven at hun er på rett vei og har noe å bygge videre på, selv om det ikke er faglige tilbakemeldinger i streng forstand. I intervjuet med Ellen trekker hun fram denne eleven og forteller at hun har bodd i Norge i ett år og har store faglige utfordringer i tillegg til språklige. Ifølge Ellen har eleven lite nytte av å følge ordinær undervisning i klassen, men elevens Norsk 2-lærer har ikke vært der de siste ukene. «Så da må jeg liksom bare tilpasse det der og da», sier Ellen. Dette utsagnet viser noe av kompleksiteten i den betingede stillasbyggingen (contingency), som ikke alltid kan planlegges fullt ut.

\section{Situasjoner fra Annes undervisning}

Utgangspunktet for veiledningssituasjonene i Annes timer er en oppgave i elevenes lærebok, Zeppelin språkbok 3 (Elsness, 2006, pp. 98-100). Det språklige temaet for skrivingen var arbeid med innledning, midtdel og avslutning. Som forarbeid fikk elevene en modelltekst om hvorfor hunden fikk kald nesetipp, der de ulike delene av teksten var tydelig markert, og Anne ledet en samtale om det typiske for innledning, midtdel og avslutning. Elevene hadde så en idédugnad om hvilke andre dyr de kunne skrive om. Med utgangspunkt i dette skulle de lage sin egen «slik gikk det til-fortelling» om et selvvalgt dyr. Eleven i det neste utdraget har valgt å skrive om hvorfor sjiraffen har lang hals. Eleven har skrevet overskriften, men ikke noe mer, og har rukket opp hånda. Læreren kommer til pulten hennes.

\section{Utdrag 3}

\section{0:43:07 - 00:44:25}

1. Lærer: Hvordan skjedde det at sjiraffen fikk lang hals? [Pause] (SS)

2. Nei...Hva kan ha skjedd? (SS) Den hadde kort.. Den hadde kort [hals], og så

3. skjedde det noe sånn at den ble lang. (I\&F) Hva kan ha skjedd? [Pause] (SS)

4. Kan den ha klemt hodet sitt i en bildør? (M) Og så kjørte bilen av gårde, så

5. bare halsen ble lenger og lenger. (M) Kan den ha vart på jakt etter mat? (M)

6. Og så stakk den hodet sitt ned i et hull og så fikk den det ikke opp igjen, og

7. så måtte den bare dra og dra. (M) Eller... kunne den på en måte ha

8. hoppa...prøvd å liksom få tak i noe som vokste høyt opp i et tre? (M) Og så

9. beit den tak i det. Og så klarte den ikke slippe taket sånn at da den landa

10. igjen ble liksom hodet sittende fast i treet også datt kroppen ned. Eller noe

11. annet... (M) Klarer du å finne på noe? (I\&F) Så hopper du over linje så det

12. blir nytt avsnitt. (I\&F)

Læreren går. Eleven sitter i 5 sekunder, så begynner hun å skrive. I løpet av økta er læreren innom eleven en gang til og ser at hun har kommet i gang. 
I intervjuet med Anne, som var videostimulert, ble hun vist opptak av denne veiledningssituasjonen. Hennes umiddelbare reaksjon etter å ha sett videoklippet var:

Det var egentlig veldig rørende. Hun er en veldig stille elev som på en måte sier veldig lite, og ... litt sånn vanskelig å veilede, fordi hun gir på en måte ikke noe uttrykk for at «nå har jeg skjønt det». Samtidig så vet jeg at hun prøver [...] og så får jeg et bittelite signal [...]. Hun gir meg et lite tegn på at «nå er jeg klar». Så tenker jeg med sånn som hun der da, at jeg ikke gir henne ett svar på at det kan ha skjedd, men at når man har tid til å si «kanskje det», eller det, det er ikke noe fasit, det er liksom du som må finne på.

Anne avslutter med å si at: «Jeg tror hun fikk god hjelp.» I dette tilfellet får intervjuet fram lærerens tanker bak veiledningssituasjonen knyttet til akkurat denne eleven. Vi ser at læreren er sensitiv for elevens behov, og at strategien hun bruker er bevisst.

Anne starter med en slags reformulering eller utdyping av oppgaven (linje 13), trolig for å forsøke å få eleven på nytt spor. Vi ser at også hun bruker spørsmål med ulike funksjoner for å lede eleven inn i kreativitetsdiskursen og skape idéer. Hun benytter imidlertid en annen strategi enn Ellen ved at hun bruker sin egen fantasi for å vise hvordan eleven kan bruke sin fantasi. Dette er altså en form for kognitiv og kreativ modellering, og spørsmålene blir en del av en mer helhetlig modelleringssituasjon. Dette viser at Van de Pol og kollegers kategorier ikke nødvendigvis er på samme nivå, og at én type stillasbyggingsstrategi kan bli brukt inn i en annen. Dette poenget blir enda tydeligere i det fjerde og siste utdraget. Denne eleven har valgt å skrive om hvorfor bjørnen har kort hale. Eleven rekker opp hånda. Læreren kommer til ham, og eleven leser noe av det han har skrevet for læreren.

\section{Utdrag 4}

\section{0:45:39 - 00:48:40}

1. Lærer: Ja, hvorfor har bjørnen kort hale? (SS)

2. Eleven leser litt til.

3. L: Ja, men ...men, her har du skrev... her har du skrevet en veldig fin

4. innledning, [navn på eleven]. Hør, skal jeg lese den for deg, så skal du høre

5. hvor flott den er. (TM)

6. Lærer leser, med innlevelse:

7. L: «Du har kanskje sett at bjørnen har kort hale? Slik har det ikke vært

8. bestandig. Her får du høre hvorfor bjørnen har kort hale.» Det er en

9. kjempeflott innledning! Og så har du huska på avsnitt. Og så har du skrevet

10. midtdelen hvor vi skal få høre hvorfor bjørnen har kort hale. Da har du

11. skrevet: «Elefanten har jo lang snabel. Da trenger den ikke lang hale.» (TM)

12. Passer det sammen? Den flotte innledningen, passer det til a

13. fortsette med der? $(\mathrm{H})$

14. Elev: $\mathrm{Nei}$ 
15. L: Nei. Det var jo ikke noen fortsettelse på den supre innledningen her. (I\&F)

16. E: Men jeg ...

17. L: Nei ...

18. E: ... kommer ikke på noe.

19. L: Nei. Nå må ..., nå må vi prøve å finne på. Vi pusser bort dette. For dette

20. hadde jo ikke noe med bjørnen og kort hale å gjøre. Er dette ...det... dette

21. skal jo handle om bjørnen og den korte halen. (I\&F)

22. E: $J a$.

23. L: Ja. Hvorfor fikk bjørnen kort hale? (SS)

24. E: Fordi ...

25. L: Hva kan ha skjedd? (SS)

26. E: Han har spist så mye ...at han...fikk kort hale.

27. L: Han har spist så mye at han fikk kort hale. (TM) Hva skjedde da? (SS)

28. E: Han ...

29. L: Kan han ha liksom satt fast halen sin et sted, sånn så den blir slitt av?

30. Eller kan han ha spist den opp? Hva skjedde? Sånn ...kanskje en dag var

31. bjørnen ute og gikk tur i skogen også møtte den en musefamilie som begynte

32. å gnage på halen hans. (M)

33. $\mathbf{E}: M m$

34. L: Og de hadde ikke spist middag, så de var kjempesultne, så de spiste opp 35. hele bjørnehalen. (M)

36. $\mathbf{E}: M m$

37. L: Eller kan han ha satt den fast i en sprekk? Og for å komme seg ut av den

38. sprekken så måtte han bare dra og dra og vipps så var halen borte. Og sånn

39. gikk det til at bjørnen har kort hale. (M) Nå må du skrive en midtdel som

40. forklarer hvorfor bjørnen har fått kort hale, hvorfor den ikke er lang lenger.

41. For den var lang før, skriver du her, så må du

42. forklare hvorfor den har blitt kort. Så må du finne på noe som gjør at den

43. liksom har blitt kort, eller at halen har blitt kort. (I\&F)

44. E: $M m$

45. L: Okay? (SS)

46. $\mathbf{E}: M m$

47. L: Flott! (TM)

Dette utdraget viser ikke oppstarten av selve skrivesituasjonen. Vi har likevel valgt å inkludere utdraget fordi det illustrerer godt en situasjon som fungerer på samme måte som en oppstartsituasjon; eleven må begynne på nytt på midtdelen, og her er han tom for idéer. I utgangspunktet inneholder dette utdraget ti spørsmål (linje 1, 12, 13, 23, 25, 27, 29, 30 og 37). Når læreren sier «Okay» i linje 45, er dette et eksempel på at denne setningsekvivalenten har funksjon som et spørsmål, men ikke er det i grammatisk forstand. Når vi har valgt å ikke markere alle spørsmålene som SS, så er det fordi spørsmålenes funksjoner er overlappende med flere av de andre strategiene for stillasbygging, for eksempel er spørsmålene 
i linje 29 og 30 en del av lærerens modellering. På den måten blir også andre aspekter ved lærerens veiledning synlige. Læreren gir en tilbakemelding (markert som TM) på det eleven har skrevet, og bekrefter at dette er en fin innledning (Svanes, 2016). Til tross for at eleven har kommet litt feil ut i skrivingen, fokuserer læreren på det som skal skje framover (jf. Hawe mfl., 2008), og til slutt gir hun noen instruksjoner (markert som I\&F) om hva som er veien videre for eleven. Også i dette utdraget modellerer læreren ved å bruke sin egen fantasi (markert som M). I utdraget ser vi hvordan en lærer i løpet av én veiledningssituasjon benytter alle de ulike strategiene i stillasbygging som er beskrevet i denne artikkelen.

Oppsummert ser vi at de to lærerne har samme formål i veiledningssituasjonene; å lede elevene over i kreativitetsdiskursen og sette dem på sporet av idéer som kan få dem til å begynne å skrive. De har derimot ulik stil og vektlegger stillasbyggingsstrategiene ulikt, noe som også selvsagt kan skyldes at skriveoppgavene er ulike. Mens Ellen leder elevene relativt tydelig inn på den veien hun vil ha dem, viser Anne et stort repertoar av strategier og ser ut til å ville gi elevene mange idéer slik at de kan velge selv. I den følgende drøftingen vil vi diskutere de ulike strategiene og kjennetegn på lærernes stillasbygging og gå dypere i på hvilken måte de kan være en del av en stillasbyggingsprosess når elevene skriver fortelling. Til slutt vil vi foreslå noen didaktiske implikasjoner av studien.

\section{Drøfting}

Gjennom denne studien har vi undersøkt hvordan to lærere i hvert sitt klasserom gir støtte til enkeltelever der elevene strever med å komme i gang med skriving av fortelling. Vi tok utgangspunkt i fem forhåndsdefinerte kategorier som er utviklet med utgangspunkt i forskningsgjennomgangen til Val de Pol mfl. (2010) av begrepet scaffolding knyttet til læring i skolen generelt, for å si noe om hva som kjennetegner disse to lærernes stillasbygging knyttet til skriving spesielt.

Analysen av samtaleutdragene viser at begge lærerne har et vidt repertoar av strategier som de bruker til å støtte enkeltelevene i å komme i gang med skrivingen. Hvilke strategier lærerne bruker, må ses i lys av at vi er helt i starten av skriveprosessen. Dette kan trolig forklare hvorfor lærerne gir lite av det vi har kategorisert som tilbakemeldinger; det er lite tekst å gi tilbakemeldinger på. Det eneste utdraget vi ser en relativt fyldig tilbakemelding $i$, er utdrag 4, men her har jo også eleven produsert tekst når læreren kommer. Vi ser at lærerne gir positive bekreftelser og ros til en viss grad, for eksempel når Anne sier at «Her har du skrevet en veldig fin innledning.» Det er derimot ikke mye bruk av ros i utdragene, kanskje fordi det ikke er så mye konkret arbeid som kan roses. Vi vil likevel presisere at i begge klasserommene observerte vi en hyggelig tone mellom lærer og elev. Kommentarer som kan virke noe harde skriftlige og transkriberte, var 
sagt i hyggelige samtaler mellom lærere og elever som kjenner hverandre godt og virket trygge på hverandre.

Lærerens valg av strategier må også ses i lys av den kreative skrivediskursen (Ivanič, 2004) og oppgavene som er gitt. Elevene har altså fått to ulike, men relativt åpne oppgaver der de har stort spillerom med hensyn til innholdet i tekstene. Det er derfor ikke unaturlig at vi i dette materialet finner at lærerne gir relativt lite direkte instruksjoner og forklaringer, mens de i stedet bruker mye spørsmål og modellering. Begge lærerne ønsker å utfordre elevene gjennom disse strategiene istedenfor for å gi ferdige svar (Dunn \& Finley, 2010; Thurlings mfl., 2013) - som da heller ikke finnes. Lærerne stiller i tråd med tidligere forskning mange spørsmål (Cazden, 2001; Mercer \& Littleton, 2007), og analysene viser at spørsmålene har ulike funksjoner. Når læreren stiller spørsmålene «Passer det sammen? Den flotte innledningen, passer det til å fortsette med der?» (utdrag 4), forventer trolig ikke læreren et ja. Det hun ønsker, er å signalisere eller hinte om at det eleven har gjort, ikke er det læreren forventer, og dette følges opp av noen forklaringer og instruksjoner der hun forteller hva eleven bør gjøre. Vi har derfor markert dette som $\mathrm{H}$, altså som hint og ikke spørsmål. Når læreren i samme utdrag spør: «Kan han ha liksom satt fast halen sin et sted, sånn så den blir slitt av? Eller kan han ha spist den opp?» er funksjonen å modellere, slik vi også var inne på i utdrag 3.

Det kan også se ut som om Ellen og Anne har ulike hensikter med spørsmålene de stiller. Begge bruker spørsmål som initiativer i samtalene og trolig med ønske om å fremkalle idéer for skrivingen. Vi ser imidlertid at Anne bruker spørsmål som åpner opp og synliggjør noen av elevenes valgmuligheter, (f.eks. «Hva kan ha skjedd?» «Kan den ha klemt hodet sitt i en bildør?») mens Ellen i større grad bruker spørsmål som snevrer inn elevens valgmuligheter (f.eks. «Har du bestemt deg for hvem som skal være hovedpersonen?» «Hva heter han?»). Ellens tilnærming samsvarer med Wood mfl. (1976, p. 98) sitt krav til stillasbyggingprosessen som «reduction in degrees of freedom». I det første utdraget bruker Ellen fire spørsmål for å mane fram idéer om hovedpersonen. Hun følger her - bevisst eller ubevisst - en strategi som er anbefalt for elever som strever med oppstart av skriving, kalt WWW (Graham \& Harris, 2005). De tre wene står for who, when, where, og strategien innebærer å stille eleven spørsmål om hvem som er med i fortellingen, når og hvor dette foregår, og gjennom dette gi eleven starthjelp. Det er vanskelig å si ut fra våre data hvilken type spørsmål som er mest effektive i stillasbyggingen. Det vi ser, er at alle elevene starter å skrive, og at lærerne ifølge intervjuene har bevisste begrunnelser for hvorfor de veileder som de gjør.

Kategorien modellering dreier seg om at læreren demonstrerer eller viser noe, som elevene kan imitere. Et aktuelt spørsmål innenfor modelltekstdidaktikken er hvorvidt elevene skal imitere eller bruke modellene som inspirasjon (Håland, 2013). Utdragene fra Annes undervisning aktualiserer dette spørsmålet. Oppgaven hun har gitt elevene inkluderer en modelltekst. I tillegg modellerer 
Anne en rekke konkrete forslag til handlingsmoment i elevenes begynnende fortelling (utdrag 3 og 4). Eleven får mange forslag å spinne videre på, men spørsmålet er om han greier å nyttiggjøre seg forslagene i arbeidet med sin fortelling, eller om han løser problemet etter lærerens oppskrift. I og med at dette er en svært tidlig fase i tekstskapingen, kan resultatet bli at elevene låses i lærerens forslag til hva fortellingen skal handle om og hvordan den skal utvikle seg, istedenfor at de støttes i å bruke fantasien til å utforske ulike måter å bygge opp fortellingen. Det er derfor relevant å stille spørsmål om lærerens forslag til utviklingen av fortellingen er hjelp mer enn stillasbygging. Vil elevene på bakgrunn av den støtten han har fått gjennom lærerens modellering i større grad være i stand til å starte opp skrivingen av en fortelling neste gang?

I samtalene mellom lærer og enkeltelever slik det framstår i datamaterialet i denne studien, ser vi at det er lærernes innspill som dominerer. Eleven svarer ofte med enstavelsesord eller bekrefter lærerens forslag, men gir i liten grad uttrykk for konkrete utfordringer eller kommer med egne forslag til løsninger. Vi viste tidligere til Myhill og Warren (2005) som hevder at for at samtaler skal fungerer som stillaser, ikke bare som sterke hint eller «tvangstrøyer», så må læreren bygge videre på det elevene sier og elevens tidligere kunnskaper og erfaringer. Utfordringen her er at eleven signaliserer at de er "tomme», de sier lite og forventer at læreren skal hjelpe dem. Det er derfor vanskelig for læreren å gjennomføre det som i teorien ville være en optimal samtale. Lærerne både stiller spørsmål og modellerer uten å nødvendigvis forvente noe svar eller direkte reaksjon fra eleven. Etter å ha analysert videoopptakene er det ikke vårt hovedinntrykk at elevene ikke kommer til orde i disse situasjonene. Inntrykket er heller at de ønsker den hjelpen de kan få. Dette samsvarer med Davidson (2007, 2008) som sier at i én til én-situasjonene er det som oftest elevene som har tatt initiativet, for eksempel ved å rekke opp hånda, i motsetning til det som er tilfelle i helklassesamtaler, der læreren ofte er den som initierer samtalen. Rent kognitivt er det derimot ikke uviktig om elevene må svare på spørsmålene eller ikke, og ifølge Van de Pol mfl. (2010) kan spørsmål betraktes som stillasbygging i kraft av at de fordrer et aktivt språklig eller kognitivt svar fra eleven. Spørsmålet om hva som er stillasbygging og hva som bare er hjelp, er helt grunnleggende for å forstå hvordan en kan støtte elevenes læring, noe Mercer (1994, s. 96) er inne på når han spør seg: «Is 'scaffolding' a description of a particular kind of teacher behavior (whatever its outcome for the pupil), or a label that can be applied to any kind of teacher intervention which is followed by learning succsess for a pupil?” I denne studien fører spørsmålene i liten grad til språklige svar. Hva eleven tenker, har vi derimot ikke kunnskap om, og vi kan derfor ikke fastslå sikkert om eleven «bare» har fått hjelp, eller om han har fått bygget et midlertidig stillas.

Lærerne lar altså de modellerte eksemplene og spørsmålene henge i luften, eller de gir eleven en instruksjon før de går til neste elev. Senere kommer lærerne gjerne tilbake til eleven igjen og ser hvordan det går. I løpet av skriveprosessen varierer læreren altså mellom å bygge stillaser gjennom dialog med eleven (step 
in) og å trekke seg tilbake (step back) slik at eleven kan skrive på egenhånd (Englert mfl., 2006). Dette kan være en måte å gi elevene rom på. De svarer ikke på spørsmålene, men overlater til elevene å reflektere rundt de spørsmålene som læreren har stilt. Å gå fra eleven på denne måten kan også være en måte å løse tidsutfordringen på. Det er ofte andre elever som trenger hjelp, og lærerne uttrykker i intervjuene at tiden er en av de største utfordringene i denne typen skriveaktiviteter. Til tross for dette ser vi at lærerne tar seg relativt god tid hos flere av elevene, for eksempel er videoopptaket som utdrag 4 bygger på, over 3 minutter langt.

\section{Didaktiske implikasjoner}

Moderne skrivedidaktikk har ikke uten grunn vært opptatt av førskrivingsfasen. Til tross for at elevene i de to observerte klasserommene har deltatt $\mathrm{i}$ ulike relevante førskrivingsaktiviteter, er det imidlertid fortsatt elever som ikke vet hva de skal skrive om i fortellingen sin. Lærere trenger altså en betydelig veiledningskompetanse for å få i gang disse elevene. Innledningsvis knyttet vi stillasbygging til begrepet contingency, forstått som støtte som ikke er direkte planlagt, men betinget av enkeltelevenes individuelle utfordringer. Det innebærer at læreren må ha klart for seg enkeltelevenes behov eller utfordringer, altså de individuelle vilkårene eller betingelsene som er bestemmende for stillasbyggingen. Læreren trenger også fagdidaktisk kunnskap (Glasswell \& Parr, 2009) som må sitte i ryggmargen fordi det er liten tid til å tenke seg om, jamfør Ellens utsagn «Så da må jeg bare tilpasse der og da». Muntlig veiledning i skrivesituasjoner er krevende å gi siden skrivesituasjoner er komplekse, og læreren har liten mulighet til å reflektere rundt og omformulere tilbakemeldingene (Harris, 1986). Dette gjelder kanskje særlig når det ikke er noen tekst å veilede på.

\section{Konklusjon}

Siden vi i denne studien har konsentrert oss om oppstartsituasjonene, vet vi ikke hvordan elevene nyttiggjorde seg den støtten de fikk av læreren. Ifølge Mercer (1994, s. 97) er det imidlertid ikke først og fremst hvorvidt elevene lykkes eller mislykkes i en konkret læringssituasjon som er kjennetegnet på om lærerens støtte kan karakteriseres som stillasbygging i motsetning til bare hjelp. Kriteriene for stillasbygging er knyttet til en utvikling hos elevene som er mer stabil ved at eleven når en ny erkjennelse eller forståelse rundt problemet og selv er i stand til å løse tilsvarende problem. Van de Pol mfl. (2010) uttrykker dette som fading og transfer of responsibility, som dreier seg om en gradvis tilbaketrekking av lærerstøtte, samtidig som eleven i økende grad overtar kontrollen over læringen (2010, s. 275). Studier av gjentakende og tilsvarende situasjoner over tid ville 
trolig kunne gi oss mer innsikt i på hvilken måte og i hvilken grad elevene eventuelt internaliserer lærerens støtte.

Det denne studien imidlertid kan bidra med, er å utfordre læreren til å gi elevene støtte i den konkrete oppstartsituasjonen på en slik måte at det er mulig for elevene mer konkret å sette ord på sine utfordringer i oppstartsfasen, ut over at de uttrykker at de ikke vet hva de skal skrive. Det dreier seg altså om samtaler rundt skriveideer der elevene på sikt kan ta i bruk noen av de samme strategiene som læreren bruker for å løse det konkrete problemet med idetørke. Som vi har sett i utdragene, er spørsmålstilling en slik strategi. Med bakgrunn i datamaterialet i denne studien mener vi at det ligger et didaktisk potensial i samtalen mellom lærer og elev til å utfordre elevene til for eksempel å stille spørsmål eller se for seg alternative løsninger knyttet til teksten sin, slik at de i neste skrivesituasjon mer aktivt og konstruktivt kan møte opplevelsen av mangel på skriveideer.

\section{Om forfatterne}

Ingvill Krogstad Svanes er førsteamanuensis ved Institutt for grunnskole- og faglærerutdanning. Hennes forskningsinteresse er norskdidaktikk på barnetrinnet, grunnleggende lese- og skriveopplæring, samtaler i norskklasserommet.

Institusjonstilknytning: Institutt for grunnskole- og faglærerutdanning, OsloMet, Postboks 4, St. Olavs plass, 0130 Oslo

E-post: inksva@oslomet.no

Anne Kristine Øgreid er førsteamanuensis ved Institutt for grunnskole- og faglærerutdanning. Hennes forskningsinteresse er lesing og skriving i og på tvers av fag, læreres støtte og tilrettelegging av den andre lese- og skriveopplæringen, kvalitative forskningsmetoder.

Institusjonstilknytning: Institutt for grunnskole- og faglærerutdanning, OsloMet, Postboks 4, St. Olavs plass, 0130 Oslo

E-post: annekr@oslomet.no

\section{Referanser}

Andersson-Bakken, E. (2014). Læreres bruk av spørsmål og responser i helklasseundervisning på ungdomstrinnet. Institutt for lærerutdanning og skoleforskning, Det utdanningsvitenskapelige fakultet, Universitetet i Oslo, Oslo.

Bakke, J. O. \& Skovholt, K. (2015). «Å forestille betyr å bruke fantasien til å tenke på noe som ikke fins» - Introduksjon av skriveoppgaver på 7. trinn. In H. Otnes (Ed.), Å invitere elever til skriving. Ulike perspektiver på skriveoppgaver. Bergen/LNU: Fagbokforlaget.

Bueie, A. (2015). Summativ vurdering i formativ drakt - elevperspektiv på tilbakemelding fra heldagsprøver i norsk. Acta Didactica Norge, 9(1). 
Bueie, A. (2016). Nyttige og mindre nyttige lærerkommentarer - slik elevene ser det. Nordic Journal of Literacy Research, 2(1).

Cazden, C. B. (2001). Classroom discourse. The language of teaching and learning (2 ed.). Portsmouth: Heinemann.

Cazden, C. B. \& Beck, S. W. (2003). Classroom discourse. In A. C. Graesser, M. A. Gernsbacher \& S. R. Goldman (Eds.), Handbook of discourse processes (pp. 165-197). Mahwah, N.J Lawrence Erlbaum

Davidsen, A. \& Aamaas, Å. (2017). Mysterier som læringsstrategi i lærerutdanning - en casestudie ved Høgskolen i Sørøst-Norge. In L. Frers, M. Bøe \& K. Hognestad (Eds.), Metode mellom forskning og lcering: Refleksjon i praksis (pp. 161-180). Oslo: Cappelen Damm.

Davidson, C. (2007). Routine Encounters During Independent Writing: Explicating Takenfor-granted Interaction. Language and Education, 21(6), 473-486. doi:10.2167/le699.0

Davidson, C. (2008). Talk about Text during Independent Writing: What Teacher-Student Interaction Suggests for How We Understand Students' Competence. Contemporary Issues in Early Childhood, 9(1), 27-35.

Dockrell, J. E., Lindsay, G., Connelly, V. \& Mackie, C. (2007). Constraints in the production of written text in children with specific language impairments. Exceptional Children, 73(2), 147-164.

Dunn, M. W. \& Finley, S. (2010). Children's Struggles with the Writing Process: Exploring Storytelling, Visual Arts, and Keyboarding to Promote Narrative Story Writing. Multicultural Education, 18(1), 33-42.

Elsness, T. F. (2006). Zeppelin : Språkbok 3. Oslo: Aschehoug.

Engelsen, K. S., Eide, T. \& Meling, B. (2009). Er "kjempebra" godt nok? Spesialpedagogikk(3).

Englert, C. S., Mariage, T. V. \& Dunsmore, K. (2006). Tenets of sociocultural theory in writing instruction research. In Handbook of writing research (pp. 208-221). New York: Guilford Press.

Flyvbjerg, B. (2010). Fem misforståelser om casestudiet. In S. Brinkmann \& L. Tanggaard (Eds.), Kvalitative metoder (pp. 463-487). København: Hans Reitzels Forlag.

Glasswell, K. \& Parr, J. M. (2009). Teachable moments: Linking assessment and teaching in talk around writing. Language Arts, 86(5), 352.

Graham, S. \& Harris, K. (2005). Writing better. Effective strategies for teaching students with learning difficulties. Baltimore: Brookes.

Harris, M. (1986). Teaching One-to-One: The Writing Conference. Urbana: National Council of Teachers of English.

Hawe, E., Dixon, H., \& Watson, E. (2008). Oral feedback in the context of written language. The Australian Journal of Language and Literacy, 31(1), 43.

Hoperstad, M. H. \& Semundseth, M. (2013). Førskolelærers praksis og femåringers skriving i formelle læringssituasjoner i en norsk barnehage. Nordic Studies in Education, 32(03-04)), 297-310.

Håland, A. (2013). Bruk av modelltekstar i sakprega skriving på mellomtrinnet : ei undersøking av korleis modelltekstar set spor i elevtekstar og korleis elevar posisjonerer seg i ulike sakprega skrivesituasjonar. Universitetet i Stavanger, Det humanistiske fakultet, Nasjonalt senter for leseopplæring og leseforsking, Stavanger.

Håland, A. (2018). Hvordan samtaler lærer og elever om modelltekster? Et bidrag til modelltekstdidaktikken. Acta Didactica Norge, 12(1).

Igland, M. (2009). Ein ettertankens didaktikk: om forståinga av pedagogisk tekstrespons. In O. K. Haugaløkken, L. S. Evensen, F. Hertzberg \& H. Otnes (Eds.), Tekstvurdering som didaktisk utfordring (pp. 24-34). Bergen: Universitetsforlaget. 
Ivanič, R. (2004). Discourses of writing and learning to write. Language and Education, 18(3), 220-245.

Kellogg, R. T. (2008). Training writing skills: A cognitive developmental perspective. Journal of writing research, $1(1)$.

Kverndokken, K. (2014). Elevers tekstskaping - øve eller skape selv. Om eksempeltekster, skriverammer, lærermodellering og samforfatterskap. In K. Kverndokken (Ed.), 101 skrivegrep: om skriving, skrivestrategier og elevers tekstskaping (pp. 36-55). Bergen: Fagbokforlaget Vigmostad \& Bjørke AS.

Kvithyld, T. \& Aasen, A. J. (2011). Fem teser om funksjonell respons på elevtekster. Tidsskriftet Viden om lessning(9), 10-16.

Larsen, A. S. (2011). «Fin fortelling. Godt jobba $\square$, Om respons på norskfaglige tekster. In J. Smidt, R. Solheim \& A. J. Aasen (Eds.), På sporet av god skriveopplæring (pp. 115-126). Trondheim: Tapir.

Lorentzen, V. (2014). «Skjermopptak - et vindu inn i elevens skriveprosess: "Hvis æ bruke tankekart eller nå sånt [...] - da hekse æ mæ sjøl". In T. Kringstad \& T. Kvithyld (Eds.), Vurdering av skriving (pp. 113-140). Bergen: Fagbokforlaget

Matre, S. (2009). Vurdering av samtaletekstar som didaktisk utfordring. In L. S. Evensen, F. Hertzberg, H. Otnes \& O. K. Haugaløkken (Eds.), Tekstvurdering som didaktisk utfordring (pp. 139-149). Oslo: Universitetsforlaget.

Mercer, N. (2010). The analysis of classroom talk: Methods and methodologies. British Journal of Educational Psychology, 80(1), 1-14.

Mercer, N. \& Littleton, K. (2007). Dialogue and the development of children's thinking : a sociocultural approach. London: Routledge.

Myhill, D. (2006). Talk, talk, talk: Teaching and learning in whole class discourse. Research papers in education, 21(1), 19-41.

Myhill, D. \& Warren, P. (2005). Scaffolds or straitjackets? Critical moments in classroom discourse. Educational Review, 57(1), 55-69. doi:10.1080/0013191042000274187

O'Keefe, C., Xu, L. \& Clarke, D. (2006). Kikan-Shido: between desks instruction. In D. Clarke (Ed.), Making connections: mathematics classrooms around the world (pp. 15-37). Rotterdam: Sense.

Parker, M. \& Hurry, J. (2007). Teachers' use of questioning and modelling comprehension skills in primary classrooms. Educational Review, 59(3), 299-314. doi:10.1080/00131910701427298

Regan, K. \& Berkeley, S. (2012). Effective reading and writing instruction: A focus on modeling. Intervention in School and Clinic, 47(5), 276-282.

Semundseth, M. H., M.H. (2010). Hiv og hoi. Brevskriving til Kaptein Sabeltann - en meningsfull skrivesituasjon i klasserommet på 1. trinn? In J. Smidt (Ed.), Skriving i alle fag - innsyn og utspill (pp. 67-87). Trondheim: Tapir Akademisk Forlag.

Svanes, I. K. (2016). Individuell veiledning på barnetrinnet - Hva gjør lcereren når elevene arbeider individuelt i norsktimene? (Doktoravhandling), Universitetet i Oslo, Oslo.

Svanes, I. K. \& Andersson-Bakken, E. (2018). En lærers bruk av spørsmål som stillasbygging i lese- og skriveopplæringen. In K. Palm \& E. Michaelsen (Eds.), Den viktige begynneroppleringen (pp. 163-186). Oslo: Universitetsforlaget.

Svanes, I. K. \& Klette, K. (2017). Teachers' instructional practices during pupils’ individual seatwork in Norwegian Language arts. Education Inquiry, 9(3), 247-266.

Tharp, R. G. \& Gallimore, R. (1989). Rousing minds to life: Teaching, learning, and schooling in social context. Cambridge: Cambridge University Press.

Thurlings, M., Vermeulen, M., Bastiaens, T. \& Stijnen, S. (2013). Understanding feedback: A learning theory perspective. Educational Research Review, 9, 1-15. 
Van de Pol, J., Volman, M. \& Beishuizen, J. (2010). Scaffolding in teacher-student interaction: A decade of research. Educational Psychology Review, 22(3), 271-296.

Voerman, L., Korthagen, F. A., Meijer, P. C. \& Simons, R. J. (2014). Feedback revisited: Adding perspectives based on positive psychology. Implications for theory and classroom practice. Teaching and Teacher Education, 43, 91-98.

Vygotsky, L. S. (1978). Mind in society : the development of higher psychological processes. Cambridge, Mass: Harvard University Press.

Wong, J. \& Waring, H. Z. (2009). 'Very good'as a teacher response. ELT journal, 63(3), 195203.

Wood, D., Bruner, J. S. \& Ross, G. (1976). The role of tutoring in problem solving. Journal of child psychology and psychiatry, 17(2), 89-100.

Øgreid, A. K. (2016). Skriveramme som støtte i arbeidet med fagskriving? Studie av 8. klasse elevers tekstskaping i samfunnsfag. Acta Didactica Norge, 10(1).

Øgreid, A. K. (2018). Skriftlig argumentasjon i fagspesifikke skrivekontekster på ungdomstrinnet. (Doktoravhandling), Universitetet i Oslo, Oslo. 